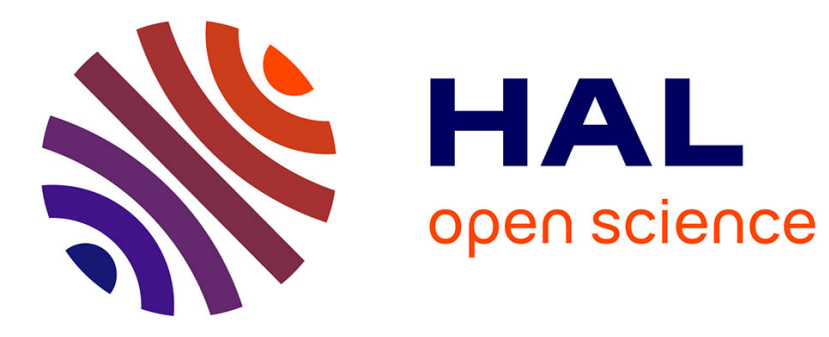

\title{
Low temperature ion-nitriding of Fe-Mo-C sintered steels
}

\author{
A. Molinari, B. Tesi, T. Bacci, G. Pradelli
}

\section{To cite this version:}

A. Molinari, B. Tesi, T. Bacci, G. Pradelli. Low temperature ion-nitriding of Fe-Mo-C sintered steels. Journal de Physique IV Proceedings, 1993, 03 (C7), pp.C7-949-C7-954. 10.1051/jp4:19937146 jpa00251768

\section{HAL Id: jpa-00251768 https://hal.science/jpa-00251768}

Submitted on 1 Jan 1993

HAL is a multi-disciplinary open access archive for the deposit and dissemination of scientific research documents, whether they are published or not. The documents may come from teaching and research institutions in France or abroad, or from public or private research centers.
L'archive ouverte pluridisciplinaire HAL, est destinée au dépôt et à la diffusion de documents scientifiques de niveau recherche, publiés ou non, émanant des établissements d'enseignement et de recherche français ou étrangers, des laboratoires publics ou privés. 


\title{
Low temperature ion-nitriding of Fe-Mo-C sintered steels
}

\author{
A. MOLINARI, B. TESI, T. BACCI* and G. PRADELLI* \\ Dipartimento di Ingegneria dei Materiali, University of Trento, Via di Mesiano 77, 38050 Trento, Italy \\ * Dipartimento di Meccanica e Tecnologie Industriali, University of Florence, Via di S. Marta 3, 50139 \\ Firenze, Italy
}

\begin{abstract}
The nitridability at low temperatures $(723-773 \mathrm{~K})$ of $\mathrm{Fe}-\mathrm{Mo}-\mathrm{C}$ sintered steels has been studied: the possibility to realize hardened surface layers of appropriate characteristics has been examined also to reduce surface microstructure alterations (e.g. decarburization) and size and shape variations which may occur for thermochemical treatments at higher temperatures. In a semi-industrial ion-nitriding plant FeMo 1.5-C 0.3 (with martensitic matrix) and Fe-Mo 1.5-C 0.5 (with bainitic matrix) sintered steels have been ion-nitrided at temperatures included in the range $723 \div 823 \mathrm{~K}$ and for treatment times of $4 \div 24 \mathrm{~h}$. As previously noticed, the first sintered steel, if ion-nitrided at $823 \mathrm{~K}$ for more than $8 \mathrm{~h}$, presents a surface hardness of about $700 \mathrm{HV}$ but also a sharp hardness fall (down to $450 \mathrm{HV}$ ) immediately beyond the compound layer owing to decarburization phenomena. Reducing the treatment temperature $(773 \mathrm{~K})$ this effect does not appear: the nitrided layer shows a regular hardness profile, with maximum hardness value of $720 \mathrm{HV}$ and thickness of about $100 \mu \mathrm{m}$, and consists essentially of the $\mathrm{Fe}_{4} \mathrm{~N}^{\prime}$ cubic nitride and $\mathrm{Fe}_{2-3}(\mathrm{C}, \mathrm{N}) \in$ hexagonal carbonitride. At the same time, the ion-nitriding treatment in the temperature range $723 \div 823 \mathrm{~K}$ has been applied to the second sintered steel. In this case, no decarburization has been observed also for treatments at the highest temperature; the hardness profiles show a gradual decrease from $730 \mathrm{HV}$ to the matrix value (350 HV), but the hardness depth results very limited also for treatment times of $24 \mathrm{~h}$.
\end{abstract}

\section{Introduction}

In the surface treatment of iron sintered alloys the use of the ion-nitriding process results of particular interest to produce hardened surface layers, characterized by high wear and corrosion resistance, on mechanical components [1-7]. In some previous works ion-nitriding experiments were carried out on sintered iron alloys of industrial use with different chemical composition, using chromium, copper, molybdenum, phosphorus and carbon as alloying elements [8-10]. The results confirmed the liability of the ion-nitriding treatment to improve the surface mechanical properties of these materials and allowed to verify the Fe-Mo 1.5-C 0.3 sintered alloy as one of the most suitable. In fact, this alloy needs a relatively simple sintering process (especially, in comparison with chromium alloyed materials) and presents a good response to the thermochemical treatment when ion-nitrided in the quenched and stress relieved conditions $[9,10]$. This behaviour of the quenched and stress relieved material with regard to its nitridability can be attributed to its homogeneous microstructure of martensitic type. The surface hardness was optimized by treating this sintered steel at $823 \mathrm{~K}$ for $4 \mathrm{~h}$ in a $\mathrm{N}_{2} 80 / \mathrm{H}_{2} 20$ atmosphere: in fact, an increase of the treatment time did not improve the hardness profile owing to decarburization phenomena which influence hardness negatively [10]. In order to reduce these negative effects, ion-nitriding treatments were planned and carried out at temperatures lower than the above indicated. It is well known, in fact, that decarburization is enhanced by temperature. In addition, a low temperature ion-nitriding can be advantageous as it causes a further reduction of the already low size and shape variations typical of this thermochemical treatment $[11,12]$.

At the same time, this treatment has been applied to the Fe-Mo 1.5-C 0.5 sintered steel, that has been recently proposed as particularly appropriate for the ion-nitriding process at the sintered state, that 
presents a uniform bainitic matrix owing to the material chemical composition [13].

It can be observed that, if a good nitridability of this material was verified, the heat treatment of quenching and stress-relieving, before the ion-nitriding process, would be un-necessary, on the contrary of what happens for the Fe-Mo 1.5 -C 0.3 sintered steel.

Thus, in the present paper the results of ion-nitriding experiments carried out in the temperature range $723 \div 823 \mathrm{~K}$ on samples realized in the Fe-Mo $1.5-\mathrm{C} 0.5$ sintered steel are reported and compared with the equivalent ones obtained on the Fe-Mo 1.5-C 0.3 sintered steel ion-nitrided in the quenched and stress-relieved conditions.

\section{Experimental Procedure}

The sintered steels samples, employed in the experimental tests, were produced using pre-alloyed Fe-Mo and graphite powders in the due percentages. Their chemical compositions, density and matrix microstructure, as well as the adopted sintering parameters are shown in table I.

TAB. I - Materials characteristics.

$\begin{array}{ccccccc}\begin{array}{c}\text { Materials } \\ \text { (wt. \%) }\end{array} & \begin{array}{c}\text { Density } \\ \mathrm{g} / \mathrm{cm}_{3}\end{array} & \mathrm{~T}(\mathrm{~K}) & \begin{array}{c}\text { Sintering } \\ \text { Parameters } \\ \mathrm{t}(\min )\end{array} & \mathrm{atm} . & \begin{array}{c}\text { Matrix } \\ \text { Microstructure }\end{array} & \text { Note } \\ \text { Fe-Mo1.5-C0.3 } & 7.0 & 1,393 & 30 & \mathrm{NH}_{3} & \begin{array}{c}\text { Stress-relieved } \\ \text { martensite } \\ \text { Bainite }\end{array} & \text { (1) } \\ \text { Fe-Mo1.5-C0.5 } & 7.0 & 1,393 & 30 & \mathrm{NH}_{3} & \text { (2) }\end{array}$

(1) $=$ Sintered, quenched from $1,133 \mathrm{~K}$ in oil at $333 \mathrm{~K}$ and tempered for $2 \mathrm{~h}$ at $453 \mathrm{~K}$.

(2) = As sintered.

The ion-nitriding process has been carried out in a semi-industrial treatment plant with working conditions reported in table II.

TAB. II - Ion-nitriding working parameters.

$\begin{array}{llc}\text { Temperature } & \text { (K) } & 723-773-823 \\ \text { Time } & \text { (h) } & 4-8-24 \\ \text { Pressure } & (\mathrm{hPa}) & 8 \\ \text { Gas composition } & (\mathrm{vol} \%) & 80 \mathrm{~N}_{2}-20 \mathrm{H}_{2} \\ \text { Current density } & \left(\mathrm{mA} / \mathrm{cm}^{2}\right) & 4.5-5.5 \\ \text { Voltage } & (\mathrm{V}) & 250-350\end{array}$

The morphology of the nitrided surface layers, their microstructural constitution and the microhardness profiles have been determined through light and scanning electron microscopies, energy dispersion spectroscopy, $X$-ray diffraction analysis (Cu $k \alpha$ radiation, $\lambda=1.5406 \AA$ ) and microhardness measurements.

\section{Results and discussion}

The materials indicated in table I have been ion-nitrided at $723-773-823 \mathrm{~K}$ for $4-8-24 \mathrm{~h}$. The figure 1 shows the microhardness profiles determined in the surface layers of the Fe-Mo 1.5-C 0.3 samples nitrided at 723-773-823 $\mathrm{K}$ for $24 \mathrm{~h}$. These profiles point out a surface hardening with a maximum hardness value of about $700 \mathrm{HV}$ and a higher nitrided depth for the samples treated at low temperatures (723-773 $\mathrm{K}$ ), while for the samples treated at $823 \mathrm{~K}$ a micro-hardness fall appears clearly in correspondence with the sub-surface zone adjacent to the compound layer, as observed also in a previous paper [10]. Lower treatment times at lower temperatures $(723-773 \mathrm{~K}$ ) have caused modest results.

With reference to the microstructure of the ion-nitrided Fe-Mo 1.5-C 0.3 sintered steel, samples treated at low temperatures $(723-773 \mathrm{~K})$ pointed out a fine precipitation of carbo-nitrides in the sub-surface 
layers (fig. 2a), while samples treated at the highest temperature $(82.3 \mathrm{~K})$ for $24 \mathrm{~h}$ did not present any precipitation in the same zones (fig. 2b): this effect is to be correlated with the hardness fall and decarburization phenomena.

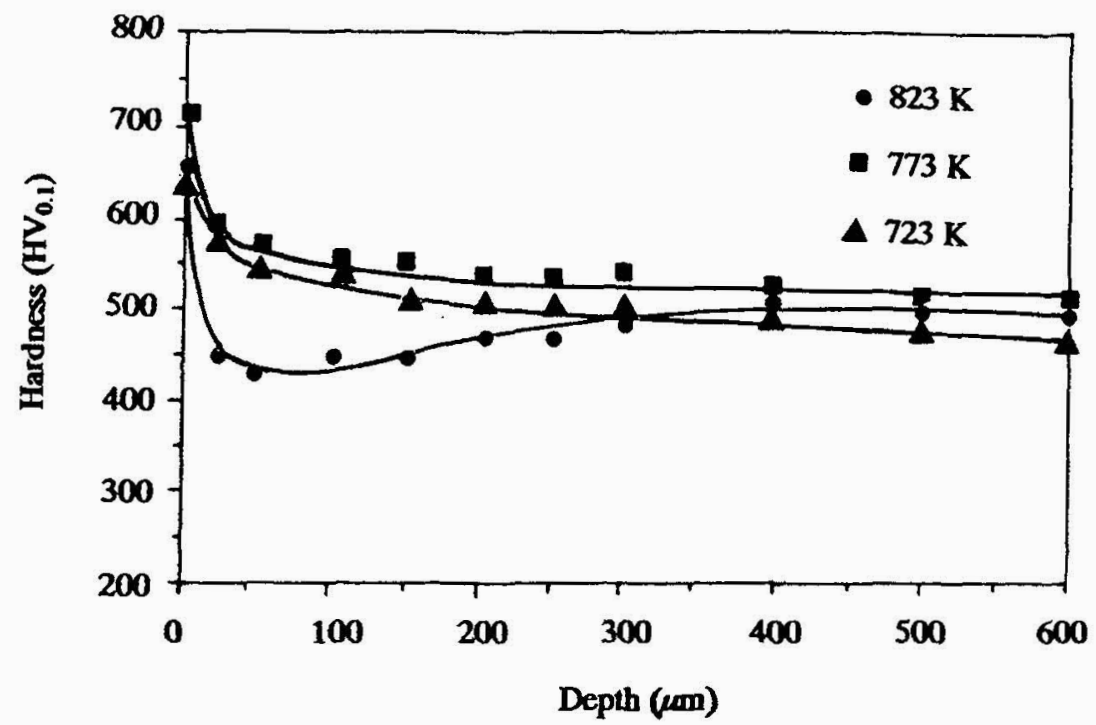

Fig. 1 - Microhardness profiles of Fe-Mo 1.5-C 0.3 sintered steel samples ion-nitrided for $24 \mathrm{~h}$.

The X-ray diffraction analyses have pointed out that the hardened surface layer of samples ion-nitrided at $823 \mathrm{~K}$ consists of the cubic nitride $\gamma^{\prime}$ prevalently and, in a reduced measure, of the hexagonal carbonitride $\epsilon$; on the contrary the samples treated at $773 \mathrm{~K}$ present the hexagonal carbo-nitride $\epsilon$ as the predominant phase of the nitrided surface layer. This behaviour has also been determined in the samples treated at $723 \mathrm{~K}$ (fig. 3). Moreover, the X-ray diffraction analysis, carried out on the residue of the dissolution of the nitrided layers in concentrated hydrochloric acid, has shown the presence of the hexagonal molybdenum carbo-nitride $\mathrm{Mo}(\mathrm{C}, \mathrm{N})[9]$.
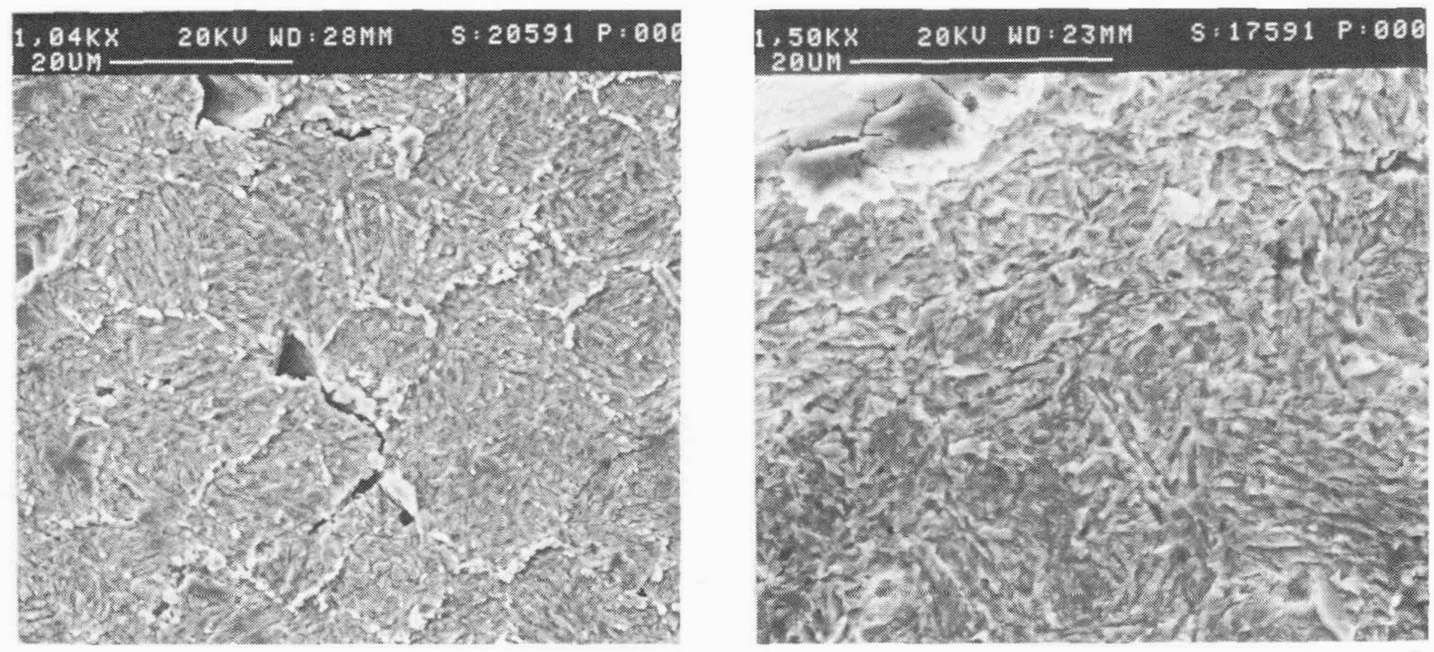

a

Fig. 2 - Sub-surface zone in Fe-Mo 1.5-C 0.3 sintered steel samples ion-nitrided for $24 \mathrm{~h}$ at: $773 \mathrm{~K}$ (a) and $823 \mathrm{~K}$ (b). 


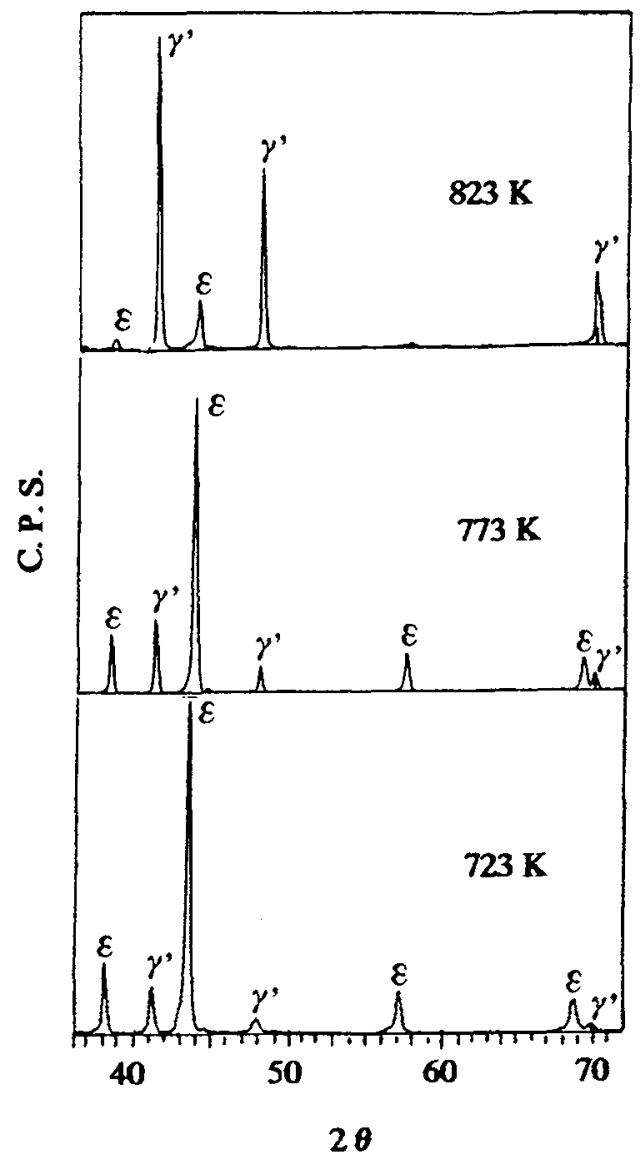

In the same way, the ion-nitriding process was carried out also for the Fe-Mo 1.5-C 0.5 sintered steel samples with the operative modalities reported in table II. As already indicated this second alloy presents a matrix consisting of bainite at the sintered state. The figure 4 shows the microhardness profiles for the surface layers of the Fe-Mo 1.5-C 0.5 sintered steel samples ion-nitrided at 723-773$823 \mathrm{~K}$ for $24 \mathrm{~h}$. It can be noted that the best results, in these experimental conditions, have been reached through treatments performed at the highest temperature $(823 \mathrm{~K})$, which in this case have not caused the microhardness fall in the hardened layers as shown, on the contrary, by the Fe-Mo 1.5-C 0.3 sintered steel. While the maximum microhardness is about $700 \mathrm{HV}$, the thickness of the nitrided depth is limited at 20-30 $\mu \mathrm{m}$ and, practically, is not affected by the treatment times.

The morphology of the ion-nitrided surface layers, shown in figure 5 , points out the presence of a compound layer with thickness of about $10 \mu \mathrm{m}$ and of a diffusion layer with a precipitation of carbonitrides in the bainitic matrix.

As a function of the ion-nitriding temperature, the evolution of the constituent phases of the hardened surface layers has been determined by $\mathrm{X}$-ray diffraction analysis and reported in figure 6 . It appears qualitatively analogous with that of the Fe-Mo 1.5C 0.3 sintered steel, with a prevalence of the $\gamma^{\prime}$ phase, in comparison with the $\epsilon$ phase, at the highest treatment temperature.

Fig. 3 - X-ray diffraction spectra of Fe-Mo 1.5-C

0.3 sintered steel samples ion-nitrided for $24 \mathrm{~h}$.

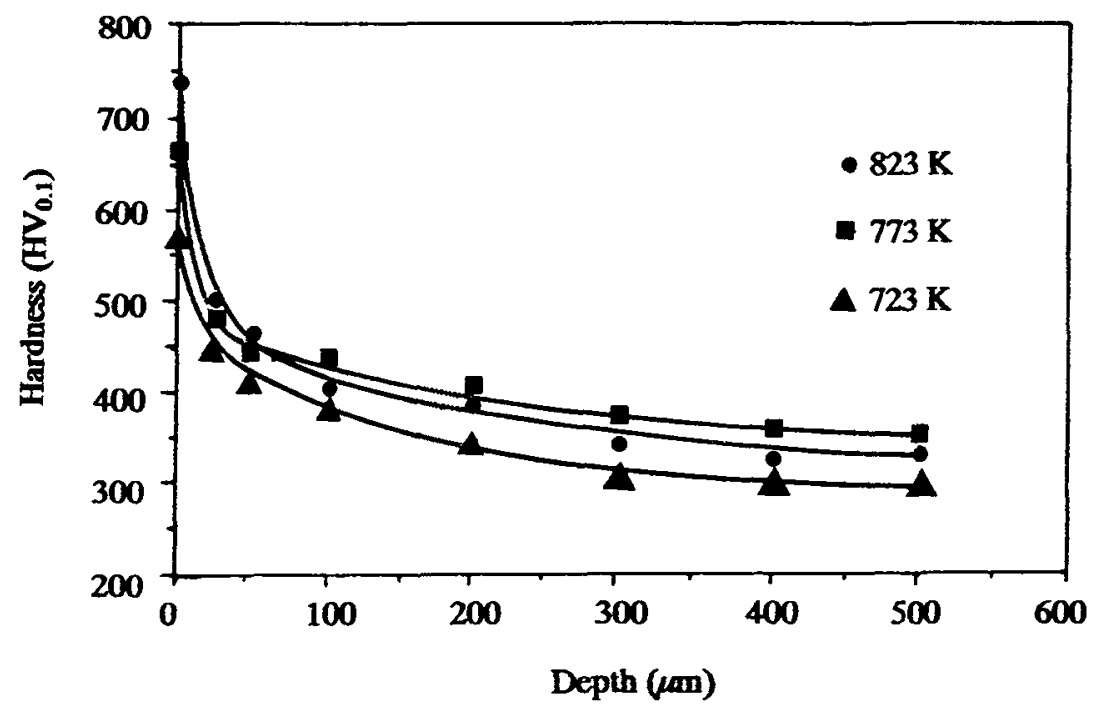

Fig. 4 - Microhardness profiles of Fe-Mo 1.5-C 0.5 sintered steel samples ion-nitrided for $24 \mathrm{~h}$. 

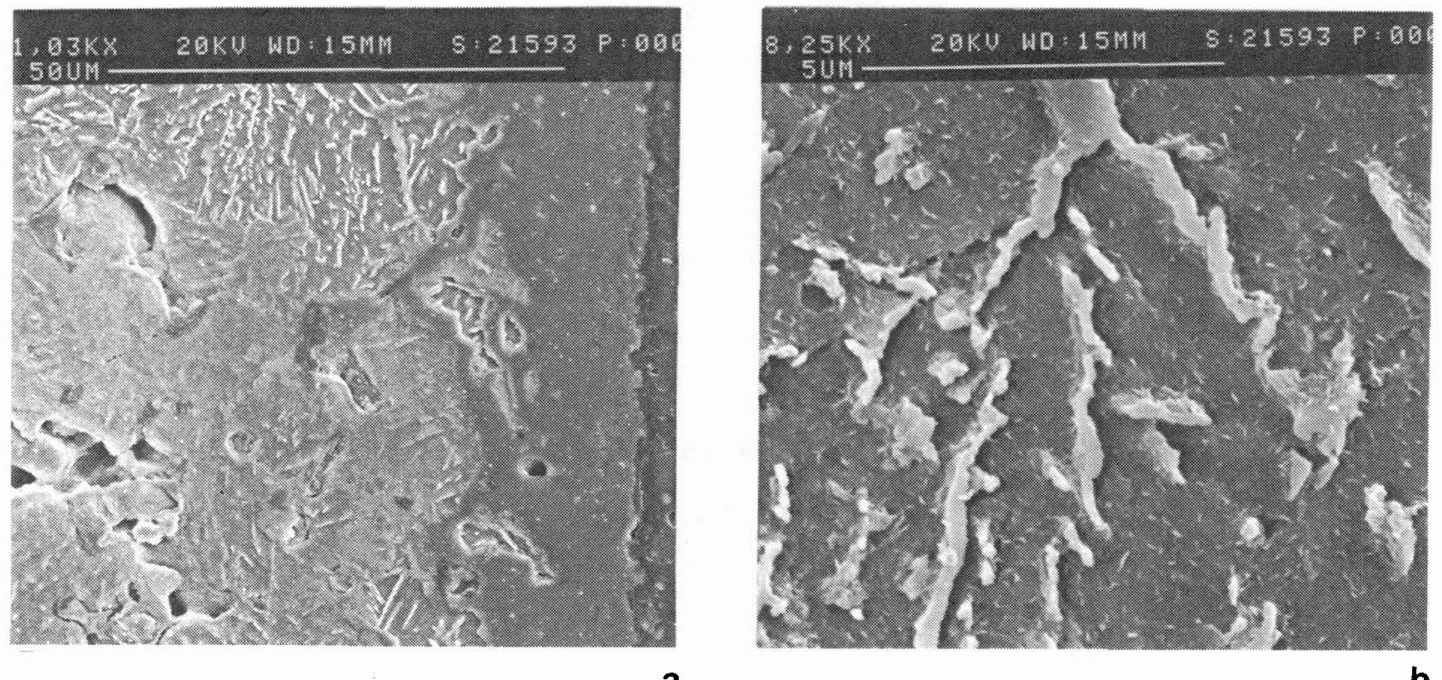

a

b

Fig. 5 - Surface layer (a) and particular of the diffusion layer (b) of Fe-Mo 1.5-C 0.5 sintered steel samples ion-nitrided at $823 \mathrm{~K}$ for $24 \mathrm{~h}$.

\section{Conclusions}

The following main conclusions can be deduced on the basis of the experimental results obtained in the course of the present research:

- The ion-nitriding treatment carried out at low temperatures (723-773 K) on samples of Fe-Mo 1.5-C 0.3 sintered steel with stress relieved martensite matrix has produced interesting surface hardness and nitrided depth; in particular, the maximum hardness has been of about $700 \mathrm{HV}$ and the nitrided layer thickness higher than 100 $\mu \mathrm{m}$ for $24 \mathrm{~h}$ treatments.

- The ion-nitrided surface layers have consisted of the cubic nitride $\gamma^{\prime} \mathrm{Fe}_{4} \mathrm{~N}$ and hexagonal carbonitride $\epsilon \mathrm{Fe}_{2-3}(\mathrm{~N}, \mathrm{C})$; the relative abundance of the $\gamma^{\prime}$ phase increased with the treatment temperature.

- The low temperature treatments of the same alloy have allowed also to avoid the decarburization of the surface layers and so the hardness fall (down to $450 \mathrm{HV}$ at $50 \mu \mathrm{m}$ depth) noticed in samples ion-nitrided at $823 \mathrm{~K}$ for $24 \mathrm{~h}$.

- In comparison with the above mentioned material (Fe-Mo 1.5-C 0.3, quenched and stress-relieved) the Fe-Mo 1.5-C 0.5 sintered steel with bainitic matrix (as sintered) has been tested; ion-nitriding treatments, carried out with the same modalities (at 723-773-823 $\mathrm{K}$ for $4-8-24 \mathrm{~h}$ ), have produced comparable values of surface hardness but nitrided depths notably reduced (about $30 \mu \mathrm{m}$ ) also for $24 \mathrm{~h}$ treatments.

- No decarburization phenomenon has been noticed in the surface nitrided layers of samples in Fe-Mo 1.5-C 0.5 sintered steel with bainitic matrix, also for treatments at the highest temperature for $24 \mathrm{~h}$.

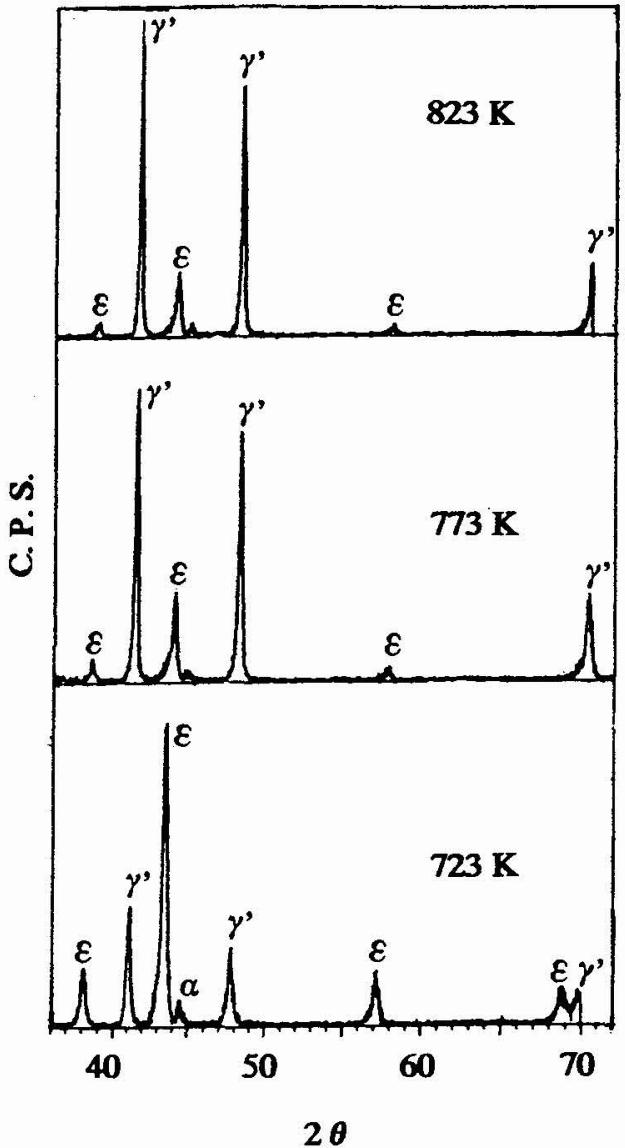

Fig. 6 - X-ray diffraction spectra of Fe-Mo 1.5-C 0.5 sintered steel samples ion-nitrided for $24 \mathrm{~h}$. 
- With the adopted experimental modalities, the Fe-Mo 1.5-C 0.3 sintered steel, with stress-relieved martensitic matrix, has presented a better nitridability and the possibility to be successfully ion-nitrided also at low temperature (723-773 K).

\section{Acknowledgements}

The authors wish to thank Hogänäs A.B. (Sweden) for supplying the specimens used in the experimental tests.

\section{References}

[1] BAS J.A. and MOLINS C., Horizons in Powder Metallurgy, Verlag Schmid Gmbh, Freiburg (1986), 365.

[2] CHEN Y.T., Progress in Powder Metallurgy 43, (1987), 593.

[3] RIE K.T., LAMPE T. and EISEMBERG S., Horizons in Powder Metallurgy, Verlag Schmid Gmbh, Freiburg (1986), 361.

[4] BELL T. and DUNFORD N., Powder Metallurgy, 1, (1980), 8.

[5] REMBGES W., Metal Powder Report, 11, (1988), 765.

[6] TOSIC M.M., TERZIC I. and GLIGORIJEVIC R., Vacuum 40, 1-2, (1990), 131.

[7] BOCCHINI G.F., MOLINARI A.,TESI B. and BACCI T., Metal Powder Report, 11, (1990), 772.

[8] MOLINARI A., TESI B., TIZIANI A., BACCI T. and BOCCHINI G.F., La Metallurgia Italiana $82,3,(1990), 275$.

[9] PRADELLI G., BACCI T., TESI B., MOLINARI A. and BOCCHINI G.F., La Metallurgia Italiana 84, 3, (1992), 243.

[10] TESI B., MOLINARI A., TIZIANI A. and BACCI T., Proc. 8th International Congress Heat \& Surface '92, Kyoto (1992), Jap. Techn. Inf. Serv., Tokyo (1992).

[11] SHAPOSHNIKOV V.N., Vestn Masinostr 7, (1981), 55.

[12] REMBGES W. and ZIMMERMANN W., Advances in Powder Metallurgy 4, (1992), 41.

[13] ENGSTROM U., LINDBERG C. and TENGZELIUS J., Powder Metallurgy 35, 1, (1992), 67. 